С. В. Шпак ${ }^{1}$, С. Г. Кислиця ${ }^{2}$, Г. М. Кожушко ${ }^{2}$ Т. В. Сахно ${ }^{3}$, С. Багиров ${ }^{4}$

${ }^{1}$ Державне підприємство «Полтавський регіональний науково-технічний центр стандартизації, метрології та сертифікації, Полтава, Україна

${ }^{2}$ Національний університет «Полтавська політехніка імені Юрія Кондратюка», Полтава, Україна

${ }^{3}$ Вищий навчальний заклад Укоопспілки «Полтавський університет економіки і торгівлі», Полтава, Україна

${ }^{4}$ Азербайджанський технічний університет, Баку, Азербайджан

\title{
МЕРЕХТІННЯ ОСВІТЛЕНОСТІ ТА СТРОБОСКОПІЧНИЙ ЕФЕКТ, ЩО УТВОРЮЮТЬ СВІТЛОДІОДНІ ЛАМПИ ТА СВІТИЛЬНИКИ
}

\begin{abstract}
Анотація . В роботі аналізуються результати останніх досліджень впливу мерехтіння світла на виконання зорових робіт, самопочуття та здоров'я людей, методи вимірювання параметрів мерехтіння та видимості стробоскопічного ефекту, а також безпечні рівні модуляції світла в різних частотних діапазонах, що встановлюються міжнародними стандартами. Досліджувались параметри мерехтіння світла, що створюють світлодіодні лампи та світильники, які поставляються на ринок України, вплив конструктивних особливостей цих виробів на рівень мерехтіння та особливості вимірювання модуляції світла з врахуванням просторової неоднорідності випромінення світлодіодів. Вимірювання глибини модуляції, індексу мерехтіння та показника видимості стробоскопічного ефекту проводили у відповідності з рекомендаціями стандартів IEEE 1789:2015 та IEC/TR 63518:2018 з використанням спектрометра MK350S. Для зміни кута спостереження використовували гоніофотометр GO2000. Результати досліджень показали, що переважна більшість світлодіодних ламп і світильників мають низькі рівні мерехтіння і не створюють ніяких ризиків для здоров'я людей, але окремі виробники виготовляють продукцію, що мають небезпечний рівень мерехтіння. Зроблені висновки про необхідність внесення в нормативні документи на світлодіодну продукцію вимог до граничних рівнів модуляції для різних частотних діапазонів. Через кутову неоднорідність спектрального складу випромінення світлодіодів має місце і кутова неоднорідність глибини модуляції. На основі досліджень глибини модуляції в залежності від кута спостереження для різних конструкцій світильників зроблені рекомендації стосовно вдосконалення методик вимірювання.
\end{abstract}

Ключові слова: індекс мерехтіння, корельована колірна температура, модуляція світла, стробоскопічний ефект, часові світлові артефакти

\section{Вступ}

Постановка проблеми. Швидка повторювана зміна яскравості світла в часі спричиняе такі відомі явища як мерехтіння (пульсації) та стробоскопічний ефект. Загальна назва цих явищ запропонована в [1]- часові світлові артефакти (temporal light artefacts, TLA). Терміном «мерехтіння» визначається зміна яскравості (або колірності) світла, що безпосередньо сприймається спостерігачем. «Стробоскопічний ефект» - це ефект який може стати видимим для спостерігача при освітленні рухомого об’єкта.

Джерела світла, які створюють мерехтіння або стробоскопічний ефект вважаються такими, що не можуть забезпечувати якісне освітлення. Як мінімум мерехтіння створює дискомфорт, але воно може стати й небезпекою для здоров'я - спричиняти втому, напруженість очей, знижувати продуктив-ність зорових робіт, провокувати головний біль, мігрені, створювати неврологічні проблеми такі як епілептичні припадки, посилювати аутистичну поведінку у дітей та ін. [2-6].

Причинами TLA можуть бути як зовнішні чинники так і конструктивні особливості світлових приладів, зокрема режими живлення, конструкції пускорегулюючих апаратів (ПРА), електромагнітні шуми в мережах, широтно-імпульсне модулювання (ШІМ) при застосуванні регуляторів потужності (димерів) тощо.
В даний час для кількісної оцінки мерехтіння часто використовують глибину модуляції (modulation dept, MD) та індекс мерехтіння (flicker index, FI) [7], але в ряді публікацій показано, що обидва ці показники не повністю здатні об'єктивно оцінити рівень мерехтіння з точки зору як насправді вони сприймаються людиною [8].

Нової актуальності проблема мерехтіння набула після широкого впровадження в технології освітлення світлодіодів, особливо при використанні ШІМ для регулювання потужності світлодіодних ламп та світильників. При ШІМ модуляції звичайно використовуються частоти від 100 до 400 Гц, причому глибина модуляції становить $100 \%$. В порівнянні з лампами розжарювання (ЛР) та розрядними лампами (РЛ) мерехтіння світла світлодіодних ламп та світильників можуть суттєво відрізнятись через надзвичайно швидку реакцію зміни світлового потоку на зміну струму. Зміна наступає через кілька наносекунд, в той час коли в РЛ вона сягає 200 мкс. Це може привести до помітних побічних ефектів які були менш помітними при освітленні ЛР та РЛ.

В [8] відзначається, що зараз важливо зрозуміти як модуляція світла світлодіодів впливає на здоров'я людини і як впливають технологічні фактори на модуляцію світла цих джерел.

Це стосується перш за все пристроїв в яких використовуються ШІМ, пульсацій вихідного струму випрямлячів 3 ємнісними та індуктивно-ємнісними фільтрами та ін. 
Зважаючи на актуальність проблеми Міжнародна комісія з освітлення (МКО) в 2011 р. створила технічний комітет ТК 1-83 «Visual aspects of timemodulated lighting systems», який розробив дорожню карту досліджень пов'язаних з модуляцією світла, що необхідні для розроблення міжнародних стандартів.

Аналіз останніх досліджень і публікацій. МКО на основі узагальнення результатів останніх досліджень TLA в Технічних записках [1] рекомендував нові уточнені визначення понять мерехтіння та стробоскопічного ефекту, що відрізняється від термінів наведених в [9]. Зокрема, МКО визначає термін мерехтіння як сприйняття візуальної нестабільності, викликаної світловим подразником, яскравість або спектральний розподіл якого коливається 3 часом, для статичного спостерігача в статичному середовищі. Мерехтіння - це один 3 типів TLA. Стробоскопічний ефект - це зміна сприйняття руху, викликаного світловим стимулом, яскравість або спектральний розподіл якого коливається 3 часом, для статичного спостерігача в нестаціонарному середовищі. Для прямокутної періодичної флуктуації яскравості рухомі об'єкти сприймаються як дискретні (а не безперервні) переміщення. Якщо частота періодичних коливань яскравості збігається $з$ частотою обертання об'єкта та цей об’єкт сприймається як статичний.

Третій тип TLA - це фантомний ефект масиву, що визначається як зміна сприйманої форми або просторових позицій об'єктів, яскравість або спектральний розподіл яких коливається з часом для нестатичного спостерігача в статичному середовищі.

В [7] аналізуються результати досліджень біологічних ефектів мерехтіння в нових технологіях світлодіодного освітлення. Вплив мерехтіння на здоров’я людей може розділити на такі, що є результатам короткочасного впливу (епілептичні випадки) i такі, що є результатом тривалого впливу, наприклад, головний біль, порушення зору, втома при виконанні зорових робіт. Перші викликаються ви- димим мерехтінням, як правило в діапазоні частот 3 Гц-70 Гц, а другі з невидимою модуляцією світла на частотах вище тих, на яких візуально сприймається мерехтіння. Біологічний вплив на людину - це функція глибини модуляції, частоти мерехтіння, яскравості та інших факторів. В роботі [3] узагальнено результати досліджень щодо впливу мерехтіння на біологічні процеси та умови їх виникнення. Зокрема, відзначається, що в діапазоні частот 3 Гц70 Гц до ризиків належать судоми у осіб які мають діагноз епілепсії, а також деякі специфічні неврологічні симптоми в тому числі нездужання та головний біль. Менш очевидними біологічні ефекти виникають при дії невидимого мерехтіння. Це перенапруження очей, втома, головний біль. Візуальне мерехтіння - небажаний атрибут для будь-якої системи освітлення, а ризики залежать від глибини модуляції і інших параметрів мерехтіння, наприклад, від поля зору.

Мета статті - дослідження параметрів мерехтіння та видимості стробоскопічного ефекту створюваних світлом світлодіодних ламп та світильників, що поступають на ринок України, впливу конструктивних особливостей ламп та світильників на рівень мерехтіння та особливостей вимірювання глибини модуляції світла з врахуванням просторової неоднорідності випромінення світлодіодів.

\section{Основна частина}

Точкові джерела світла мають меншу ймовірність викликати судоми та головний біль, ніж розсіяне світло, яке охоплює більшу частину сітківки ока. Найбільша ймовірність виникнення епілептичних припадків припадає на частоти 15-20 Гц. Незначні ризики мають місце також при низьких яскравостях (менше $1 \mathrm{\kappa д} / \mathrm{M}^{2}$ ) і монотонно зростають при зростанні яскравості. Червоне мерехтіння з великою глибиною модуляції та чередуванні червоних та синіх спалахів можуть бути особливо небезпечними.

В табл. 1 наведені інтервали частот в яких виникають різні біологічні ефекти.

Таблиця 1 - Біологічні ефекти, що виникають при різних частотах модуляції світла

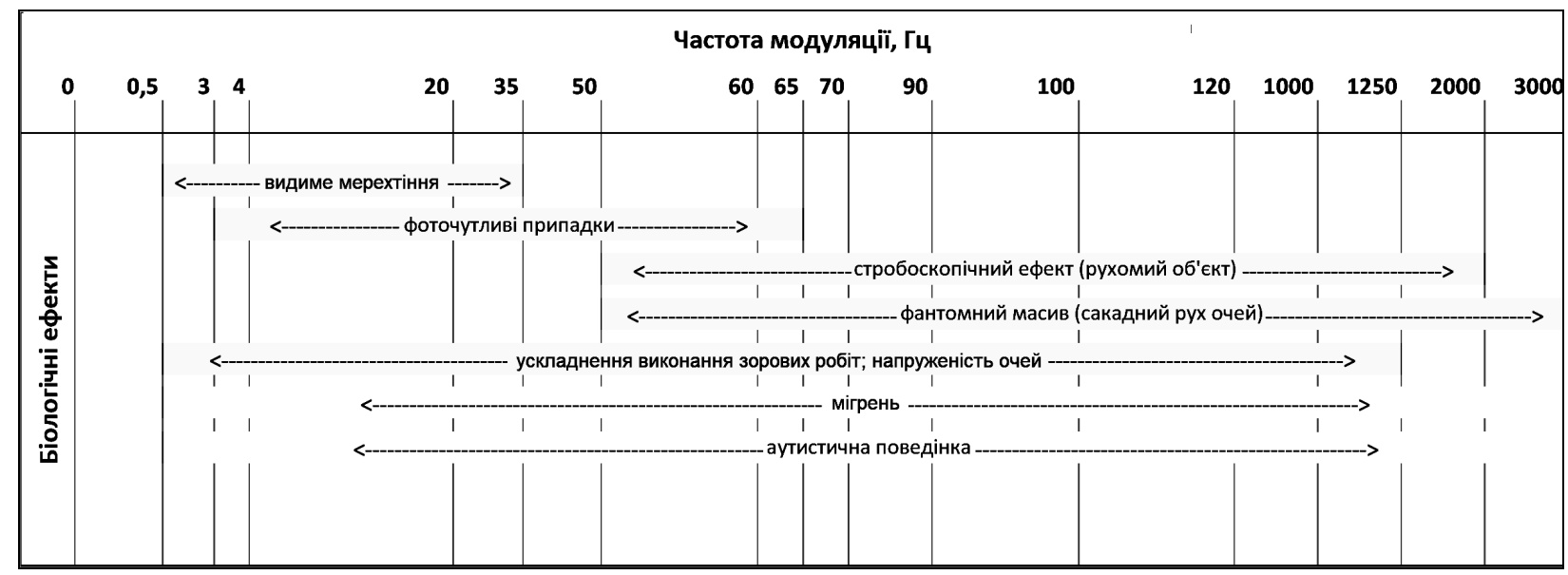

В [2] сформульовані критерії, які можуть пом'якшити біологічні ефекти мерехтіння світла при використанні світлодіодних ламп та світильників.
Мерехтіння залежить від параметрів драйверів (ПРА), що застосовуються в лампах та світильниках, системах управління освітленням (димерах) та ін- 
ших зовнішніх впливів (якості напруги в електромережі, електричних завад, що створюються різними споживачами електроенергії та ін.). Проб-леми 3 мерехтінням доцільно вирішувати в кожному випадку індивідуально.

Мерехтіння має найбільше значення в загальному освітлені житлово-побутових приміщень, дитячих, шкільних та медичних закладів, промислових приміщеннях $з$ рухомою технікою та робочих місць 3 напруженою зоровою роботою та ін. Критерії низького ризику мерехтіння світла та методи їх оцінювання рекомендовані в наступних нормативних документах [10-14].

Інститут інженерів 3 електротехніки та електроніки [7] узагальнив дані багатьох незалежних досліджень і сформулював такі критерії:

1) глибина модуляції

$$
\operatorname{Mod} \%=\left(L_{\max }+L_{\min }\right) /\left(L_{\max }-L_{\min }\right) \times 100
$$

де $L_{\max }, L_{\min }$ - відповідно максимальна та мінімальна яскравість), що відповідає низькому рівню ризику на частотах нижчих ніж 90 Гц має не перевищувати числові значення (у відсотках), що визначаються 3 виразу

$$
\operatorname{Mod} \% \leq 0,025 \cdot f \text {, }
$$

( $f$ - частота модуляції);

2) при $f>90$ Гц допустима глибина модуляції визначається із виразу

$$
\operatorname{Mod} \% \leq 0,08 \cdot f \text {, }
$$

На основі сформульованих критеріїв в [7] рекомендовані такі практики.

Рекомендована практика 1. Для обмеження можливих несприятливих біологічних ефектів глибина модуляції не повинна перевищувати $0,025 \cdot f$ для частот нижче 90 Гц. В інтервалі частот 90-1250 Гц глибина модуляції має бути чисельно менше $0,08 \cdot f$; вище 1250 Гц по глибині пульсації обмежень немає.

Рекомендована практика 2. Якщо потрібно забезпечити рівень NOEL (No observable effect level) (відсутній будь-який біологічний вплив на організм людини), то слід зменшити пульсації в 2,5 рази в порівнянні з рекомендованою практикою 1, тобто:

- нижче 90 Гц - глибина пульсації має бути менше $0,01 \cdot f \%$;

- в межах від 90 Гц до 3000 Гц - глибина пульсації має бути меншою $0,0333 \cdot f \%$;

- вище 3000 Гц обмеження на пульсації відсутні.

Рекомендована практика 3. (запобігання виникнення фоточутливих епілептичних припадків). Глибина модуляції для частот нижче 90 Гц має бути менше ніж $5 \%$. Для врахування коливань форми хвилі використовують FI. Він встановлює зміну яскравості протягом періоду відносно іiі середнього значення. FI визначається як відношення площі $\mathrm{S}_{1}$ до суми $\mathrm{S}_{1}+\mathrm{S}_{2}$ (рис. 1.). Для якісного освітлення FI не повинен перевищувати значення 0,1 .

Головним недоліком методики оцінювання мерехтіння наведеної в [7] $є$ те, що вона не враховує сприйняття мерехтіння в залежності від частот.

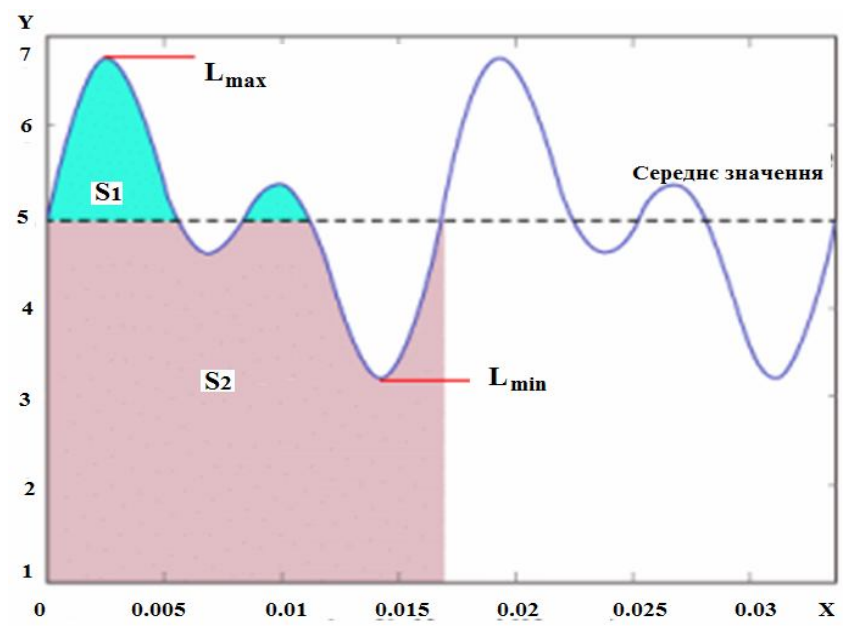

Рис. 1. До визначення глибини модуляції та індексу мерехтіння FI.

В [14] рекомендується об'єктивний метод для оцінювання мерехтіння з врахуванням його сприйняття спостерігачем на різних частотах в діапазоні 3-60 Гц. На рис. 2. наведено порогові значення модуляції виявленні з ймовірністю 50 \% в залежності від частоти. На графіку (б) - чутливість до виявлення мерехтіння, розрахована із експериментальної залежності виявлення модуляції (рис. 2).
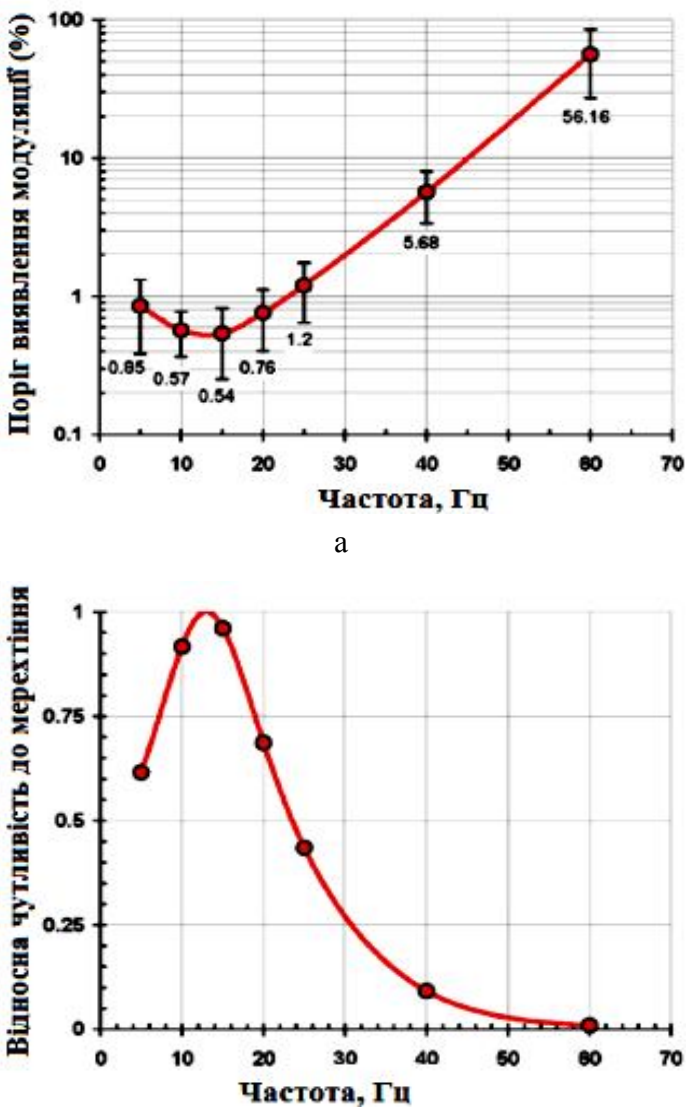

6

Рис. 2. Порогові значення модуляції при різних частотах (а) та чутливість до виявлення мерехтіння - (б) [14].

Як видно з рис. 2. при частоті 15 Гц спостерігач може виявити мерехтіння при відносній глибині модуляції 0,5 \%, тоді як при частоті 60 Гц для вияв- 
лення мерехтіння потрібна модуляція майже $60 \%$. Результуючі значення модуляції для кожної частоти виражаються через пороги виявлення і позначають як $\mathrm{M}_{\mathrm{pк}}$.

Модуляція, що сприймається і відповідає пороговому значенню (виявляється 3 вірогідністю 50 \%) приймається за одиницю. При значеннях менших одиниці виявити мерехтіння не можливо, а при значно більших - виявляється легко. Якщо мерехтіння в інтервалі 3-60 Гц має різні частоти, то результуюче сприймання модуляції $\mathrm{M}_{\mathrm{p}}$ визначають як

$$
M_{p}=\sqrt{\sum_{k}(M p k)^{2}}
$$

де $k=1,2,3 \ldots$

Результуюче значення $\mathrm{M}_{\mathrm{p}}$ інтерпретується так

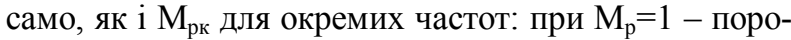
гові значення, що виявляються з вірогідністю 50 \%; при $\mathrm{M}_{\mathrm{p}}<1$ - мерехтіння не видимі; при $\mathrm{M}_{\mathrm{p}}>1$ - мерехтіння виявляється легко.

В $[12,15]$ описаний об'єктивний метод оцінювання мерехтіння світла, що грунтується на стандартах, в яких встановлені методи вимірювання та вимоги до приладів для точного сприйняття коливання напруги [16]. Мерехтіння оцінюється короткотерміновим показником мерехтіння (short-term flicker indicator, $\mathrm{P}_{\mathrm{st}}$ ), світлові параметри якого виміряні за допомогою флік метра, що відповідає вимогам [16]. Позначається цей показник $\mathrm{P}_{\mathrm{st}}^{\mathrm{LM}}$. За результатами вимірювань інтерпретація випробування наступна:

- при $\mathrm{P}_{\mathrm{st}}^{\mathrm{LM}}=1$ досліджуване джерело світла має рівень мерехтіння, який виявляє спостерігач 3 вірогідністю $50 \%$, такий як і в лампах розжарювання потужністю 60 Вт;

- при $\mathrm{P}_{\mathrm{st}}^{\mathrm{LM}}<1$ - джерело світла має рівень мерехтіння нижчий, ніж у ламп розжарювання потужністю 60 Вт;
- $\quad$ про $\mathrm{P}_{\mathrm{st}}^{\mathrm{LM}}>1$ - рівень мерехтіння вищий ніж у ламп розжарювання і його легко виявити.

Що стосується оцінювання стробоскопічного ефекту, то об'єктивний метод вимірювання видимості стробоскопічного ефекту (stroboscopic effect visibility, SVM) запропонований в стандарті [13]. Розглянуті в цьому документі умови виникнення стробоскопічного ефекту обмежуються оцінкою при освітленостях більше 100 лк та при помірних швидкостях об'єкту (<4 м/с). SVM не оцінюється впливи мерехтіння на здоров'я і не $\epsilon$ мірою для оцінки небажаних стробоскопічних ефектів в промисловості. Метод розрахований для оцінки TLA в офісах, житлових приміщеннях та аналогічних умовах.

Числові значення SVM можуть коливатись в межах від 0 до 9. При SVM = 0 будь-яка модуляція світла відсутня, тоді як при $\mathrm{SVM} \approx 9$ модуляція прямокутної форми (з безкінечно малою тривалістю імпульсу) дорівнює $100 \%$.

Результати SVM можна інтерпретувати наступним чином [13]:

- при SVM=1 - стробоскопічний ефект, що створює модуляція світла $є$ на порозі видимості. Це означає, що середній спостерігач може виявити стробоскопічний ефект з ймовірністю 50 \%;

- якщо значення $\mathrm{SVM}<1$, то ймовірність виявлення менша $50 \%$, а якщо SVM>1 - то ймовірність буде вищою $50 \%$.

На рис. 3 наведені граничні рівні модуляції згідно $з$ критеріями установленими в [7]. Тут же наведена лінія безпечного рівня мерехтіння, що оцінюється за допомогою $\mathrm{P}_{\mathrm{st}}^{\mathrm{LM}}$ та умови видимості стробоскопічного ефекту SVM.

Рівень модулювання, при якому відсутні будь-які біологічні впливи на організм людини має бути в 2,5 рази менший, ніж визначений виразами (1) та (2).

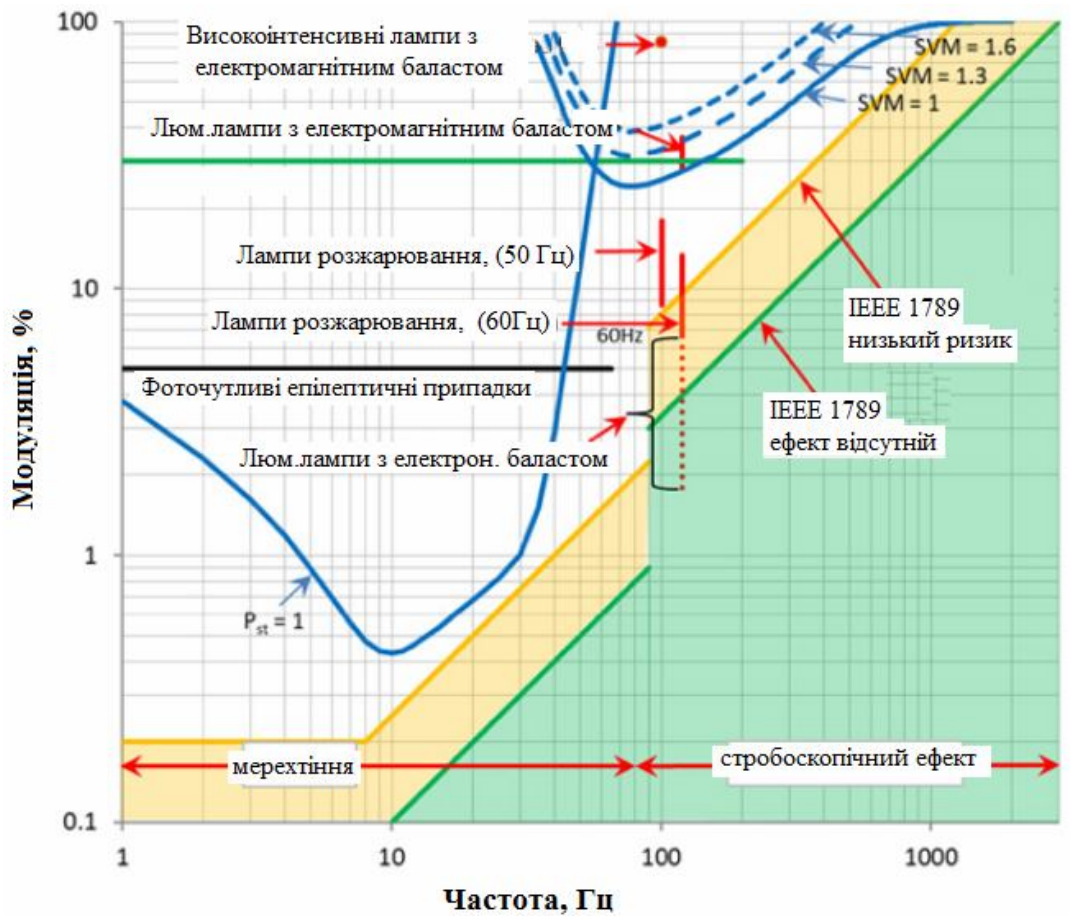

Рис. 3. Граничні рівні глибини модуляції за стандартами $[7,12,13]$ 
Слід також зазначити, що рівень сприймання TLA може бути набагато вищою межі видимості. Сприймання залежить від тривалості впливу, швидкості руху об'єкту та інших факторів [13].

Із порівняння вимог різних нормативних документів до низького рівня ризику, що створює мерехтіння або рівня NOEL видно, що найбільш жорсткими вони $\epsilon$ в стандарті [7]. Навіть лампи розжарювання, в яких глибина модуляції на частоті 100 Гц становить $12-15 \%$ не відповідають вимогам рекомендованої практики 1 цього стандарту. Тому в ряді публікацій, наприклад, в [17] пропонується замість показників MD та FI запропонованих в [7] використовувати для оцінювання рівня мерехтіння $\mathrm{F}_{\mathrm{st}}^{\mathrm{LM}}$, a для стробоскопічного ефекту - SVM. Ці вимоги менш жорсткі, враховують частоту, форму хвилі і які фактично можуть передбачити видимість мерехтіння та стробоскопічного ефекту.

Дослідження причин, що спричиняють модуляцію в світлодіодних лампах та світильниках проводилось в багатьох наукових працях, огляд яких наведено в $[1,2,7,18]$. Основними є конструкції драйверів, технологія регулювання світлових параметрів за допомогою димерів 3 використанням ШІМ, коливання напруги мережі живлення та завади викликані різними елект-ричними споживачами, що приєднані до мережі живлення та ін. Фактори, що визначають видимість TLA залежать як від модуляції світла, частоти, форми хвилі так і від яскравості, кута зору та ін.

Для оцінювання ступеню мерехтіння виробники світлотехнічної продукції використо-вують як показники MD та FI так i $\mathrm{P}_{\mathrm{st}}^{\mathrm{LM}}$, а для стробоскопічного ефекту - SVM. Результати дослідження пульсацій світлодіодних ламп та світильників наведено також в [19 - 22]. В Україні для визначення рівня якості світла стосовно мерехтіння використовується лише один показник - коефіцієнт пульсації (користуючись термінологією МКО - це глибина модуляціiі), а показники, що спричиняють стробоскопічний ефект взагалі не нормуються.

Метою даної роботи $\epsilon$ аналіз особливостей TLA світлодіодів, методів їх вимірювання та дослідження параметрів мерехтіння та стробоскопічного ефекту світлодіодних ламп і світильників, що поступають на ринок України з використанням методик наведених в [7, 13].

Результати дослідження. Нами досліджувалось мерехтіння, що створюють комерційні зразки світлодіодних ламп та світильників, які надходять на ринок України, а також просторова однорідність мерехтіння цих виробів. Для вимірювання глибини модуляції мерехтіння та показника видимості стробо-скопічного ефекту використовували спектрометр MK350S, а для зміни кута спостереження - гоніофотометр GO 2000. Вимірювання параметрів мерехтіння під різними кутами спостереження проводили через інтервал 10 градусів при рівні освітленості не нижче 40 лк.

Усереднені показники мерехтіння - глибину модуляції MD, індекс мерехтіння FI та показник видимості стробоскопічного ефекту SVM - вимірювали 3 використанням фотометричних куль діаметрами 1,5 м та 3 м. Результати вимірювання цих показників наведені в табл. 2.

Ризики впливу мерехтіння на організм людини оцінювали на частоті з найбільшою глибиною модуляції у відповідності з рекомендаціями [7]. Ці дані наведені на рис. 4

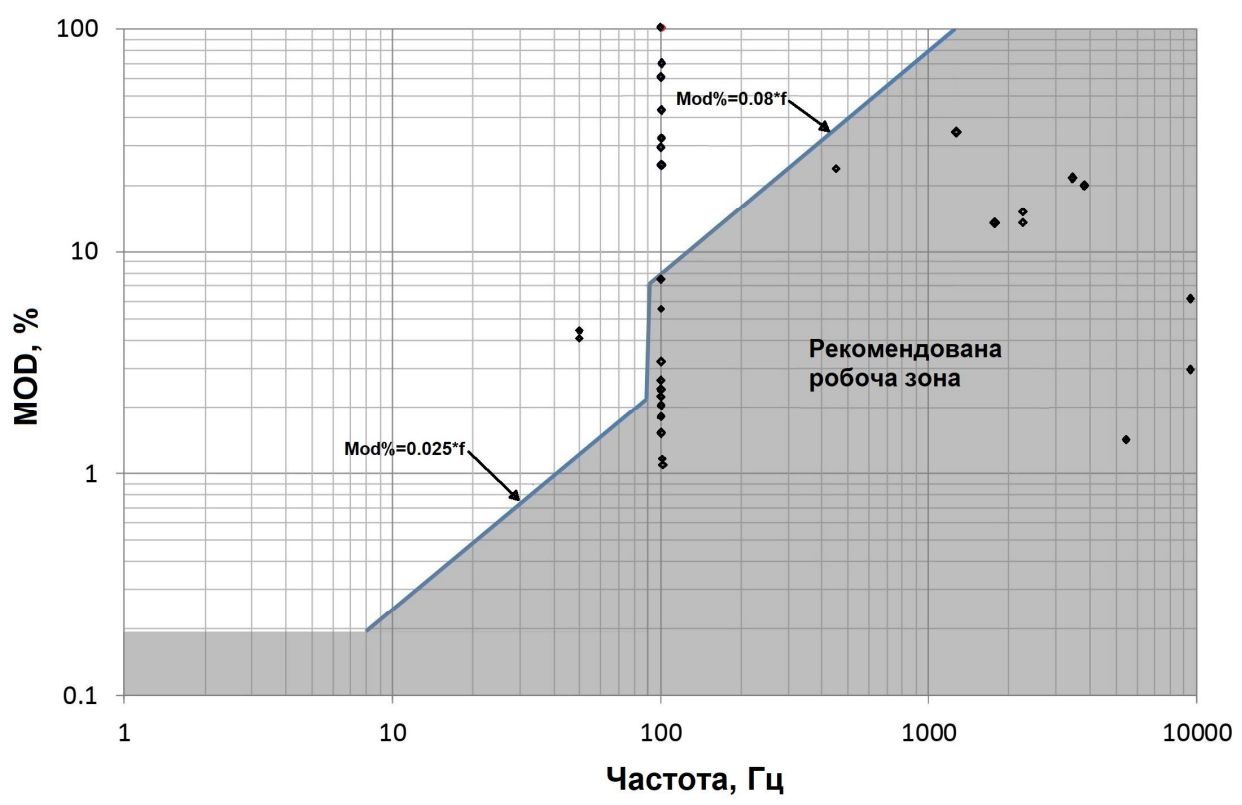

Рис. 4. Оцінювання відповідності ламп та світильників рівню безпечності мерехтіння: затемнена зона - зона низького ризику модуляції

Більшість досліджених ламп та світильників мають найбільшу глибину модуляції на частоті 100 Гц. Модуляцію меншу за граничний рівень, що відповідає низькому ризику та рівню NOEL (повна відсутність ризику) мають приблизно $70 \%$ досліджених ламп. 
Для світильників внутрішнього освітлення цей показник ще кращій, але прожектори та світильники зовнішнього освітлення в багатьох випадках мають незадовільний рівень.

В публікації [23] наголошується на важливості обмеження допустимого рівня мерехтіння світла світильників зовнішнього освітлення і перегляд діючих норм в цій сфері. Обмеження глибини модуляції і встановлення відповідних рівнів яскравості та освітленості дорожнього покриття стає новим інструментом забезпечення якості дорожнього освітлення. Мерехтіння спричиняє суттєвий вплив на учасників дорожнього руху, перш за все водіїв сучасних транспортних засобів, що обладнані моніторами. В цьому випадку до мерехтіння освітленості додаються мерехтіння яскравості і колірності моні- торів, що знаходяться в полі зору водія. Наголошується, що небезпечність працездатності водія в умовах мерехтіння освітленості доріг багаторазово перевищують ризики роботи з монітором у офісі, де нормативно обмежується рівень мерехтіння освітленості.

Виходячи 3 цього, потрібно обмежувати рівень мерехтіння яскравості та показника видимості стробоскопічного ефекту для світильників зовнішнього освітлення, зокрема для освітлення вулиць та доріг.

Для порівняння зі світлодіодними лампами та світильниками були проведені дослідження параметрів мерехтіння та видимості стробоскопічного ефекту ЛР та компактних люмінесцентних ламп (КЛЛ). Середні значення вимірювань наведені в табл. 2.

Таблиия 2 - Результати вимірювання параметрів мерехтіння світла та показника стробоскопічної видимості SVM

\begin{tabular}{|c|c|c|c|c|c|}
\hline $\begin{array}{c}\text { Назва } \\
\text { виробу }\end{array}$ & $\begin{array}{l}\text { Номер } \\
\text { зразка }\end{array}$ & $\begin{array}{l}\text { Максимальна } \\
\text { глибина } \\
\text { модуляції, \% }\end{array}$ & $\begin{array}{c}\text { Частота для макси- } \\
\text { мальної глибини } \\
\text { модуляції, Гц }\end{array}$ & $\begin{array}{c}\text { Індекс } \\
\text { мерехтіння FI, } \\
\text { відн. од. }\end{array}$ & $\begin{array}{c}\text { SVM, } \\
\text { відн. од. }\end{array}$ \\
\hline \multirow{2}{*}{ Прожектор } & 1 & 100 & 100 & 0,486 & 5,01 \\
\hline & 2 & 100 & 100 & 0,486 & 5,18 \\
\hline \multirow{2}{*}{$\begin{array}{c}\text { Світильники для } \\
\text { зовнішнього } \\
\text { освітлення }\end{array}$} & 1 & 33,11 & 100 & 0,0976 & 1,1476 \\
\hline & 2 & 36,73 & 1356 & 0,0988 & 0,0487 \\
\hline \multirow{7}{*}{$\begin{array}{c}\text { Світильники для } \\
\text { внутрішнього } \\
\text { освітлення }\end{array}$} & 1 & 1,03 & 100 & 0,0014 & 0,0052 \\
\hline & 2 & 2,36 & 100 & 0,0032 & 0,0254 \\
\hline & 3 & 1,82 & 100 & 0,0033 & 0,0099 \\
\hline & 4 & 2,6 & 100 & 0,0058 & 0,0697 \\
\hline & 5 & 5,89 & 100 & 0,0081 & 0,0884 \\
\hline & 6 & 22,3 & 400 & 0,0326 & 0,0307 \\
\hline & 7 & 1,64 & 100 & 0,0031 & 0,0111 \\
\hline \multirow{15}{*}{$\begin{array}{c}\text { Світло-діодні } \\
\text { лампи }\end{array}$} & 1 & 14,95 & 2208 & 0,0353 & 0,0415 \\
\hline & 2 & 14,28 & 1766 & 0,0355 & 0,0553 \\
\hline & 3 & 15,73 & 2204 & 0,0354 & 0,0434 \\
\hline & 4 & 43,12 & 100 & 0,1164 & 1,3940 \\
\hline & 5 & 4,05 & 50 & 0,0040 & 0,0021 \\
\hline & 6 & 3,41 & 100 & 0,0049 & 0,0345 \\
\hline & 7 & 1,11 & 100 & 0,0263 & 0,5026 \\
\hline & 8 & 2,00 & 100 & 0,0022 & 0,0092 \\
\hline & 9 & 4,01 & 50 & 0,0043 & 0,0214 \\
\hline & 10 & 6,14 & 9594 & 0,0087 & 0,0216 \\
\hline & 11 & 10,87 & 3686 & 0,0305 & 0,0250 \\
\hline & 12 & 11,39 & 3276 & 0,0307 & 0,0306 \\
\hline & 13 & 1,49 & 5234 & 0,0033 & 0,0062 \\
\hline & 14 & 3,00 & 9418 & 0,0067 & 0,0121 \\
\hline & 15 & 2,31 & 100 & 0,0053 & 0,0115 \\
\hline \multirow{5}{*}{ кЛЛ } & 1 & 15,89 & 100 & 0,0200 & 0,1834 \\
\hline & 2 & 11,91 & 100 & 0,0209 & 0,2383 \\
\hline & 3 & 15,36 & 100 & 0,0221 & 0,2370 \\
\hline & 4 & 11,50 & 100 & 0,0242 & 0,2857 \\
\hline & 5 & 7,92 & 100 & 0,0164 & 0,1912 \\
\hline ЛР & cep. 3H & 11,80 & 100 & 0,0367 & 0,4497 \\
\hline
\end{tabular}


Як бачимо у світлодіодних ламп та світильників ці показники більш безпечні ніж у КЛЛ та ЛР. Однак недоліком світлодіодних ламп та світильників $є$ те, що глибина модуляції у них може бути від 0 до $100 \%$, а у ламп розжарювання, наприклад, не більше $25 \%$, у КЛЛ - не більше 20 \%. У світлодіодів також можуть бути потенційно більшими і показники FI та SVM. Проблема тут в тому, щоб світлодіодні лампи та світильники з високим ступенем мерехтіння не потрапляли до споживачів. Більшість сучасних світлодіодних ламп та світильників мають низький рівень модуляції, який відповідає навіть самим жорстким вимогам рекомендованої практики 2 згідно з IEEE 1789:2015.

На сьогодні технології світлодіодного освітлення забезпечують найнижчий рівень мерехтіння порівняно з іншими технологіями і технічно можливо забезпечити виготовлення всієї світлодіодної продукції з низьким рівнем модуляції світла без суттєвого збільшення її вартості. Для цього, перш за все, необхідно встановити в нормативній документації відповідні вимоги, так як в даний час вони відсутні [24].

В більшості сучасних ламп і світильників для загального освітлення використовуються світлодіоди, що випромінюють синє світло, яке частково, за допомогою люмінофора, перетворюється в жовто-зелене. Співвідношення синього і жовтозеленого світла, що виходить за межі світлодіоду і визначає його колірність. Синє світло, що випромінюється кристалом світлодіоду під малими кутами до оптичної осі, розповсюджується в люмінофорі по більш короткому шляху, тому при малих кутах спостереження (ближче до оптичної осі) буде більше синього світла, а при великих кутах (ближче до $90^{\circ}$ ) - більша частка випромінення люмінофору. Це призводить до кутової нерівномірності колірності світла. А так як постійна часу для синього випромінення світлодіоду на кілька порядків менша часу випромінення люмінофору, то при пульсаціях струму мерехтіння світла, що випромінюється кристалом і люмінофором може мати різну глибину модуляції і це буде створювати кутову нерівномірність глибини модуляції.

Результатами наших досліджень підтверджено наявність такого ефекту.

Дослідження кутової неоднорідності і індексу мерехтіння проводили на світлодіодних лампах та світильниках без світлорозсіювачів елементів та 3 дифузними світлорозсіювачами. За допомогою дифузних розсіювачів світла можна досягти рівномірної колірності світла і навіть збільшити частку короткохвильового світла при великих кутах спостереження.

Зміну співвідношення в спектрі між синім та жовто-зеленим світлом під різними кутами спостереження оцінювали за значеннями корельованої колірної температури (ССТ) - при високих колірних температурах переважає синя складова світла і навпаки. На рис. 5 наведені результати вимірювання ССТ та глибини модуляції світла від кута спостереження. Як видно з рис. 5, зміна колірної тем- ператури і глибини модуляції від кута спостереження мають подібний характер.

Флікер-індекс FI змінюється від кута спостереження приблизно на такі ж відсотки як і глибина модуляції.

Різниця між максимумом та мінімумом глибини модуляції для різних досліджених зразків змінювалась від 1,8 \% до 6 \%. Це не дуже суттєва різниця, але для оцінки на відповідність вимогам нормативної документації це має значення, тому доцільно експериментально визначити і нормувати середнє значення глибини модуляції, індексу мерехтіння та SVM. Для вимірювання середнього значення параметрів мерехтіння краще застосовувати фотометричну кулю, так як цей метод значно економічніший, ніж з використанням гоніофотометра. Різниця між вимірюванням середнього значення глибини модуляції світла 3 використанням фотометричної кулі і розрахунком середнього значення за вимірюванням $з$ використанням гоніофотометра не перевищує $3 \%$.

\section{Висновки}

За результатами проведеного аналізу та експериментальних досліджень можна зробити наступні висновки.

1. Часові світлові артефакти суттєво впливають на якість світла світлодіодних ламп та світильників. Вони можуть впливати не тільки на дискомфорт, але і на здоров'я людей - спричиняти головний біль, епілептичні припадки, втому, створювати стробоскопічний ефект та інше.

2. На сьогодні не існує рекомендацій МКО щодо єдиних вимог до безпечного рівня модуляції світла і методів вимірювання параметрів мерехтіння, але є цілий ряд рекомендацій міжнародних та національних організацій різних країн в яких запро-поновані методи вимірювання та рівень безпечності параметрів мерехтіння світла та видимості стро-боскопічного ефекту. До розроблення рекомендацій МКО тимчасово можна скористатись рекомендація-ми таких стандартів як IEC/TR 615471:2015, IEEE 1789:2015, IEC/TR 62518:2017, рекомендація-ми ASSIST, NEMA, Energy Star та ін.

3. На основі експериментальних досліджень встановлено, що більша частина світлодіодної продукції, що поступає на ринок України має безпечний рівень модуляції світла та показника видимості стробоскопічного ефекту.

4. Сучасний рівень технологій виробництва світлодіодної продукції має потенціал до подальшого зменшення рівня модуляції світла і забезпечення повної відсутності ризику від мерехтіння. Заміна ламп розжарювання та розрядних ламп на світлодіодні лампи та світильники дозволить повністю вирішити проблему мерехтіння та утворення стробоскопічного ефекту в освітленні.

5. Глибина модуляції світла світильників і ламп зі світлодіодами має просторову неоднорідність, тому вимірювання показників мерехтіння та видимості стробоскопічного ефекту доцільно проводити 3 використанням інтегруючої сфери. 
CCT, $\mathrm{K}$

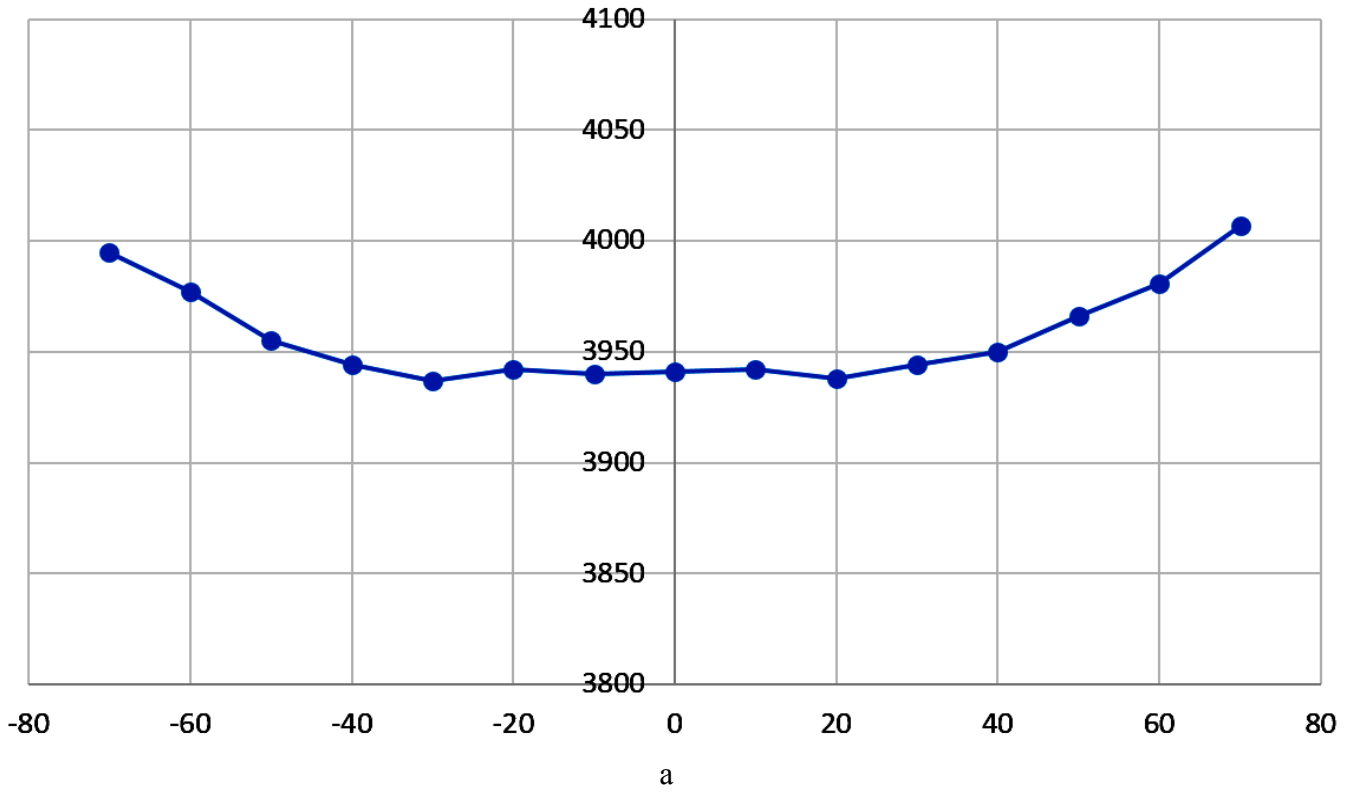

Mod, \%

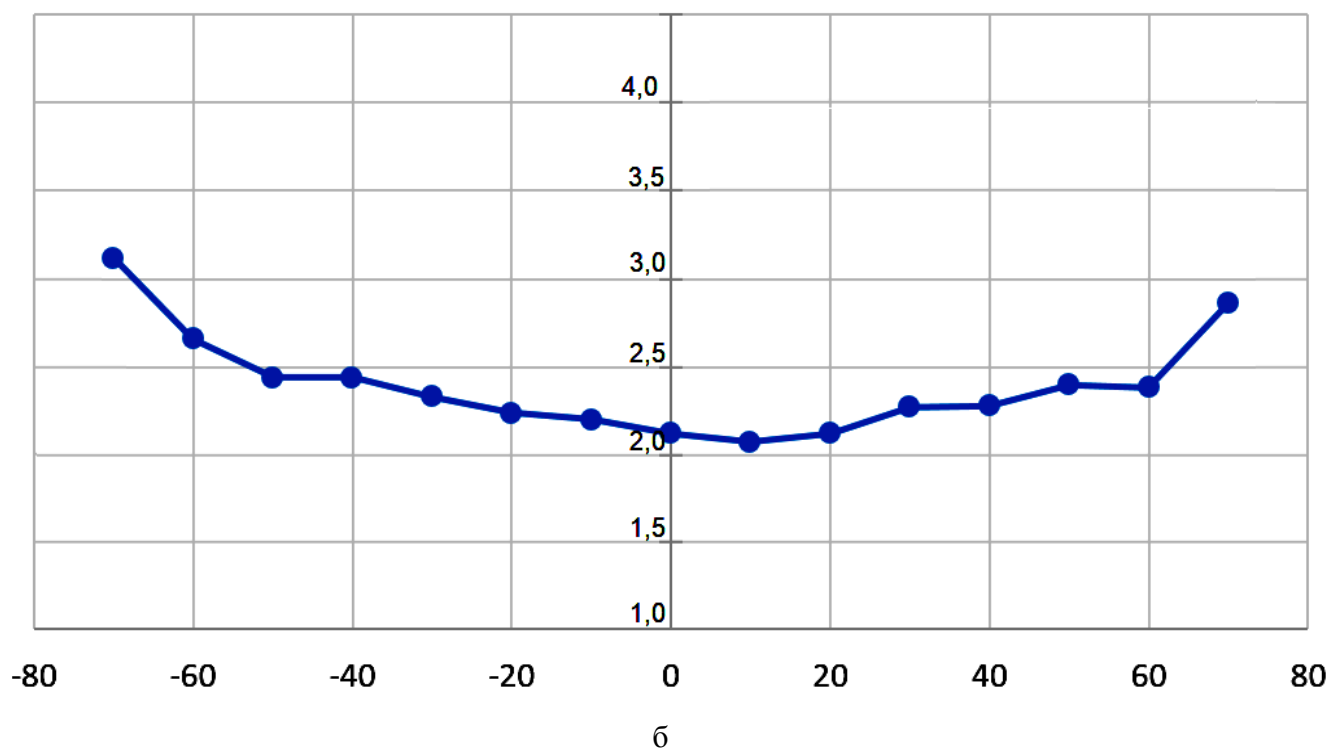

Рис. 5. Залежність колірної температури

(а - від глибини модуляції; б - від кута спостереження) для світлодіодної лампи з дифузним розсіювачем

\section{СПИСОК ЛІТЕРАТУРИ}

1. CIE TN 006:2016 Visual Aspects of Time-Modulated Lighting Systems - Definitions and Measurement Models.

2. Lehman, B. Designing to Mitigate Effects of Flicker in LED Lighting: Reducing risks to health and safety [Text] / B. Lehman, A. J. Wilkins // IEEE Power Electronics Magazine. - 2014. - Vol. 1, № 3. - P. 18-26.

3. Wilkins A. J., Veitch J., and Lehman B., "LED lighting flicker and potential health concerns: IEEE standard PAR1789 update," in Proc. IEEE Energy Conversion Congr. Expo., 2010, pp. 171-178. Wilkins A., Veitch J., Lehman B. LED lighting flicker and potential health concerns: IEEE standard PAR1789 update // Energy Conversion Congress and Exposition (ECCE). Atlanta: GA, 2010. P. 171-178.

4. Fisher R. S., Harding G., Erba G., Barkley G. L., and Wilkins A. Photicand pattern-induced seizures: A review for the Epilepsy Foundation of America working group," Epilepsia, vol. 46, no. 9, pp. 1426-1441, Sept. 2005.

5. Harding G., Wilkins A. J., Erba G., GBarkley. L., and Fisher R. S., "Photicand pattern-induced seizures: Expert consensus of the epilepsy foundation of America working group," Epilepsia, vol. 46, no. 9, pp. 1423-1425, Sept. 2005.

6. de Bittencourt P. R. M. Photosensitivity: The magnitude of the problem// Epilepsia, vol. 45, no. 1, pp. 30-34, 2004.

7. IEEE 1789-2015 Recommended Practices for Modulating Current in High-Brightness LEDs for Mitigating Health Risks to Viewers. 
8. CIE TN 008:2017 Final Report CIE Stakeholder Workshop for Temporal Light Modulation Standards for Lighting Systems.

9. ДСТУ IEC 60050-845:2012 Международный словарь электротехнических терминов. Часть 845. Светотехника (IEC 60050-845:1987, IDT).

10. Energy Star, "ENERGY STAR Method of Measurement for Light Source Flicker," 2016.

11. NEMA 77-2017 Temporal light artifacts: test methods and guidance for acceptance criteria.

12. IEC TR 61547-1:2017 Equipment for general lighting purposes - EMC immunity requirements - Part 1: An objective light flickermeter and voltage fluctuation immunity test method.

13. IEC TR 63158:2018 Equipment for general lighting purposes - Objective test method for stroboscopic effects of lighting equipment

14. ASSIST: Alliance for Solid-State Illumination Systems and Technologies Recommended Metric for Assessing the Direct Perception of Light Source Flicker - January 2015 Volume 11, Issue 3.

15. ДСТУ ЕN 61000-3-3:2017 (EN 61000-3-3:2013, IDT; IEC 61000-3-3:2013, IDT) Електромагнітна сумісність. Частина 33. Гранично допустимі рівні. Нормування змін напруги, флуктуацій напруги і флікера в низьковольтних системах електропостачання загальної призначеності для обладнання з номінальним струмом силою не більше ніж 16 А на фазу, яке не підлягає обумовленому підключенню

16. ДСТУ ЕN 61000-4-15:2018 (EN 61000-4-15:2011, IDT; IEC 61000-4-15:2010, IDT) Електромагнітна сумісність. Частина 4-15. Методики випробування та вимірювання. Флікерметр. Технічні вимоги до функціювання та конструкції

17. NEMA Position Paper, Temporal Light Artifacts (Flicker and Stroboscopic Effects), 2015-06-15: https://www.nema.org/news/Pages/NEMA-Lighting-Systems-Division-Publishes-Position-Paper-on-Temporal-LightArtifacts.aspx.

18. Castro, Ignacio \& Vazquez, Aitor \& Arias, Manuel \& G. Lamar, Diego \& Hernando, M.M. \& Sebastián, Javier. (2019). A review on flicker-free ac-dc LED drivers for single-phase and three-phase ac power grids. IEEE Transactions on Power Electronics. PP. 1-1. 10.1109/TPEL.2018.2890716. Ignacio Castro, Aitor Vazquez, Manuel Arias, Diego G. Lamar, Marta M. Hernando, Javier Sebastian A review on flicker-free ac-dc LED drivers for single-phase and three-phase ac power grid // IEEE Transactions on Power Electronics ( Volume: 34 , Issue: 10 , Oct. 2019 ) Page(s): 10035 - 10057.

19. Арексис Л. О пульсациях выпускаемых ламп / Л. Арексис ,С. Китсинелис, Ж. Циссис / Светотехника. 2012. C. $58-64$

20. Шаракшанэ А. С. Мамаев С. В. Нотфуллин Р. Ш.; Порубов А. В. Фактические значения пульсации освещенности, создаваемой современными источниками света//Оптический журнал. -2017. -84(1). - C.41-47.

21. Шпак С., Мартиросова В., Сахно Т., Кожушко Г., Дослідження пульсацій світлового потоку світлодіодних ламп та світлодіодних світильників. Промислова електроенергетика та електротехніка 2019. - 4-6.- С.22-27.

22. Shefer Alexander. Current-voltage characteristic and electroluminescence of UV LEDs $365 \mathrm{~nm}$ at liquid nitrogen temperature / Vitaly Veleschuk, Alexander Vlasenko, Zoya Vlasenko, Ihor Petrenko, Yevhen Malyi, Vladimir Borshch, Olena Borshch, Alexander Shefer // Optica Applicata, Vol. XLIX, No. 1, 2019. pp. 125-133.

23. Никифоров С. Семинар «Освещение улиц городов и автомагистралей. Стандарты и требования»/ Полупроводниковая светотехника. 2019, №6, С.16-18

24. Шпак С., Мартиросова В., Сахно Т., Кожушко Г., Напрямки вдосконалення стандартів на світлодіодну техніку та освітлення з ії використанням. Електроенергетика, електротехніка та електромеханіка, Том 1 № 154 (2020): Серія: Технічні науки та архітектура. С.57-66.

Received (Надійшла) 12.03.2020

Accepted for publication (Прийнята до друку) 29.04.2020

\section{Flickering light and stroboscopic effect} from LED lamps and light fixtures

\section{S. Shpak, S. Kyslytsia, G. Kozhushko, T. Sakhno, S. Bagirov}

Abstract. The paper analyzed the results of recent studies related to the effect of flickering light on the performance of visual work, well-being and human health. Besides, the authors described the methods for measuring the parameters of flicker and visibility of the stroboscopic effects, as well as safe levels of light modulation in different frequency ranges established by international standards. We studied the parameters of light flicker created by LED lamps and luminaires that are supplied to the Ukrainian market, the influence of the design features of these products on the level of flicker, and especially the measurement of light modulation taking into account the spatial heterogeneity of the LEDs. The modulation depth, flicker index, and stroboscopic effect visibility index were measured in accordance with the recommendations of the IEEE 1789:2015 and IEC/TR 63518:2018 standards using the MK350S spectrometer. To change the viewing angle, a GO2000 goniophotometer was used. The obtained results showed that the vast majority of LED lamps and fixtures have low levels of flicker and do not pose any risks to human health, but some manufacturers produce products that have a dangerous level of flicker. Conclusions were drawn about the necessity to introduce into the regulatory documentation the requirements for the limits of the modulation levels related to different frequency ranges observed in the LED products. It was found that due to the angular inhomogeneity of the spectral composition of the LED radiation, the angular inhomogeneity of the modulation depth also takes place. Based on studies of the depth of modulation depending on the viewing angle for various designs of luminaires, recommendations were made on improving measurement methods.

Keywords: correlated colour temperature, flicker index, light modulation, stroboscopic effects, temporal light artefacts. 